\title{
RE-UNDERSTANDING TOLERANCE THROUGH INTRARELIGIOUS DIALOGUE: the Discourse of Anti-Shi'ism in Indonesia
}

\author{
Fany N. R. Hakim \\ Center for Religious and Cross-cultural Studies, UGM \\ Email: fanyhakim@mail.ugm.ac.id
}

\begin{abstract}
Religious diversity in a country is prone to tensions between groups, especially if there is a very wide disparity between the minority and the majority. Domination by the majority over the minority may lead into discrimination and intolerance. This paper describes how the Islamic discourses of the Muslim majority in Indonesia, represented by Nahdlatul Ulama and Muhammadiyah as the largest Islamic mass organizations in Indonesia, perceive the Shia community. This paper utilizes the concept of communal tolerance developed by Jeremy Menchik to analyze how intolerance is still inherent in amongst the majority groups. Through a descriptive method, this paper refers to many relevant literature reviewed with an intra-religious dialogue approach. Considering the importance of intra-Muslim dialogue as part of attempts to redefine tolerance, discriminatory actions should be no longer experienced by minority groups.
\end{abstract}

Keywords: tolerance, communal tolerance, Shia, anti-Shi'ism, intra-religious dialogue

DOI: https://doi.org/10.20414/ujis.v25i2.449

\section{Introduction}

IN TERMS of religious diversity, every country always has issues with the majority and minorities that sometimes lead to a conflict. ${ }^{1}$ Likewise, in Indonesia, diversity and differences often become a divider in society. ${ }^{2}$ Particularly, the majority try to influence the policies in government to accommodate their interest or to protect

${ }^{1}$ Michael Hoffman, "Religion and Tolerance of Minority Sects in the Arab World," Journal of Conflict Resolution 6, no. 2-3 (2020): 433.

2 Jeremy Menchik, "Productive Intolerance: Godly Nationalism in Indonesia," Comparative Studies in Society and History 56, no. 3 (2014): 621. 
their privilege. ${ }^{3}$ Such policies often do not take into account what the minority groups need. As a result, the actualization of these policies tends to be discriminatory against, and intolerant for, the minority groups. According to van Deth et al., the majority group has a potential to make discrimination against the minority. ${ }^{4}$ In maintaining group power, many of them oppress the minority groups by restricting them from gaining full rights. The majority may also interfere the process of lwa-making so that the result will fit the interests of the majority group. The involvement of religion in the realm of politics will usually form an authoritarian government. Aauthoritarianism has emerged in discussions of political intolerance. ${ }^{5}$ Here, people's rights will depend on the status of membership in the group. According to Menchik, those who are not members of the majority group will have fewer rights. ${ }^{6}$ In this regard, Menchik calls such behavior as the majority domination. ${ }^{7}$ The domination of the majority is often normalized because in general the power is held by the majority.

In the Indonesian context, the majority Islamic religious groups are represented by some organizations. In this sense, Nahdlatul Ulama (NU) and Muhammadiyah are the largest Islamic organizations in Indonesia that influence directly or indirectly politics in the country. ${ }^{8}$ As many researchers argue, NU and Muhammadiyah are among the most tolerant Islamic organizations that accommodate the interests of minority groups and quite often promote 'religious moderation' to increase

3 Robert W. Hefner, ed., Routledge Handbook of Contemporary Indonesia (Abingdon: Routledge, 2018), 213.

${ }^{4}$ Jan W van Deth, José Ramón Montero, and Anders Westholm, eds., Citizenship and Involvement in European Democracies: A Comparative Analysis (Routledge, 2009), 118.

${ }^{5}$ Ibid., 125.

6 Jeremy Menchik, Islam and Democracy in Indonesia: Tolerance without Liberalism (New York: Cambridge University Press, 2016), 151.

${ }^{7}$ Ibid., 154.

8 Adistya Iqbal Irfani, Moh. Yasir Alimi, and Rini Iswari, "Toleransi Antar Penganut Nahdhatul Ulama, Muhammadiyah, Dan Kristen Jawa Di Batang," Jurnal Komunitas 5, no. 1 (2013): 2; Amru Almu'tasim, "Berkaca NU Dan Muhammadiyah Dalam Mewujudkan Nilai-Nilai Moderasi Islam Di Indonesia," Tarbiya Islamia 8, no. 2 (2019): 199-200. 
awareness of the human values of each of its members. ${ }^{9}$ The attitude of tolerance showed by NU and Muhammadiyah has even become an example that Islam as a religion promotes peace and human rights. However, different attitudes are sometimes shown by NU and Muhammadiyah members. Especially at the grass-root level, such attitudes are indicated by individuals affiliated with these two organizations directed towards the minority such as Shia and Ahmadis. ${ }^{10}$ Although NU and Muhammadiyah officially promote the values of pluralism, supports from their members for the fulfillment of the rights of these minority groups is still limited. ${ }^{11}$ Even with the Muslim community in general, there are those who are able to be tolerant and some are not. This shows that tolerance is not yet fully both in the sense of politics and society.

With tolerance that is pragmatic and communal, the majority still often shows discrimination by giving stereotypes to certain minority groups. ${ }^{12}$ One thing that has become a concern, even today, is anti-Shia propagation. Many parties delegitimize the existence of Shia groups in Indonesia, especially reformist Muslim organizations that carry a narrative of allegations that Shia spread heretical teachings to Indonesian people. ${ }^{13}$ As a result, the antiShia discourse has been growing along with the support of government officials and the Islamic state or non-state

${ }^{9}$ Menchik, Islam and Democracy in Indonesia: Tolerance without Liberalism.

10 Jeremy Menchik and Thomas B. Pepinsky, "Islam, Identity, and the Organizational Roots of Political Tolerance," SSRN Electronic Journal (2018): 1-29; Martin van Bruinessen, ed., Contemporary Developments in Indonesian Islam: Explaining the "Conservative Turn" (Pasir Panjang: ISEAS Publishing, 2013), 109. See also Alexander R. Arifianto, "Practicing What It Preaches? Understanding the Contradictions between Pluralist Theology and Religious Intolerance within Indonesia's Nahdlatul Ulama," Al-Jami'ah: Journal of Islamic Studies 55, no. 2 (December 15, 2017): 241-264.

${ }^{11}$ Menchik, Islam and Democracy in Indonesia, 132.

${ }^{12}$ Mukhsin Achmad, "A Hermeneutical Analysis on Fatwa of The Council of Indonesian Ulama Dealing with Discriminating Shia in Indonesia," Madania 23, no. 1 (2019): 39.

13 Zulkifli, "The Struggle of the Shi'is in Indonesia" (Leiden University, 2009), 259. 
organizations. ${ }^{14}$ There are also many Muslim intellectuals with moderate views who carry the value of pluralism voicing their support for Shia groups so that they are given space. ${ }^{15}$ They took the initiative to organize formal meetings to discuss Sunni-Shia issues in order to reduce the criminalization and stigmatization towards Shia followers. ${ }^{16}$ Such attempts through discussions seem to have not been very successful at mediating the Sunni-Shia conflict. Therefore, intrareligious dialogue is proposed as an alternative to create mutual understanding and mutual respect between Sunni-Shia, as this present study suggests.

Based on such analyses, this paper describes how tolerance develops amongst the majority Muslims toward the minority Muslim in Indonesian society by taking the case of the anti-shia discourses. It will show how such discourses influences this minority group. Various responses, both negative and positive, continue to emerge as the public became more aware of the teachings of Shia Islam, followed by the promotion of anti-Shia values through various publications. ${ }^{17}$ Many intellectual Muslims have expressed support for the Shia on behalf of the values of diversity and humanity. ${ }^{18}$ In the final section, it will explain how the Sunni-Shia dialogue is built to reduce sectarian tensions, especially in Middle Eastern countries and other Muslim worlds.

\section{The Existing Tolerance}

Jeremy Menchik in his book Islam and Democracy in Indonesia: Tolerance without Liberalism describes the meaning of tolerance as

${ }^{14}$ M. Khusna Amal, "Protecting Civil Rights Amidst Rising Illiberalism in Indonesia's Democracy: State's Response to Sharia-Based Violence Against Shi'a Groups," Ulumuna 24, no. 2 (December 31, 2020): 296-319.

15 Dicky Sofjan, "Minoritization and Criminalization of Shia Islam in Indonesia," Journal of South Asian and Middle Eastern Studies 39, no. 2 (2016): 33.

${ }_{16}$ Chiara Formichi, "Violence, Sectarianism, and the Politics of Religion: Articulations of Anti-Shi'a Discourses in Indonesia," Indonesia 98 (2014): 11.

17 Ali Muhtarom, "The Study of Indonesian Moslem Responses on SalafyShia Transnational Islamic Education Institution," Jurnal Ilmiah Islam Futura 17, no. 1 (2017): 86.

${ }^{18}$ Zulkifli, "The Struggle of the Shi' is in Indonesia." 
follows: "The willingness to put up with those things one rejects or opposes." 19

This definition refers to the aspect of political science. He divides tolerance into five levels: Full intolerance (persecution); Semi-intolerance (discrimination); Neutrality; Semi-tolerance (support); Full tolerance (recognition, cooperation, alliance). ${ }^{20}$ To him, tolerance is a concept that has ambiguity and sensitive to discuss. This sensitivity arises due to its emergence in the diversity and grouping in society.

After understanding the brief overview of the definition, we can try to understand the meaning of a more specific concept, namely communal tolerance proposed by Menchik below, "Communal tolerance is defined as the willingness to 'put up' with ideas or groups that one rejects, with rights defined by group membership." 21

He explains the concept of communal tolerance by looking at the responses and attitudes of the largest Islamic-based religious organizations in Indonesia (NU and Muhammadiyah) towards minority groups. According to him, a narrow understanding that only tends to be political makes their tolerance 'half-hearted' and incomplete. As he asserts:

"... these organizations are tolerant of religious minorities based on social and state rules that differ from John Locke and John Rawls' model of secular-liberal tolerance rooted in individual rights, the separation of church and state, and state neutrality toward religion. These organizations support tolerance based on group rights, legal pluralism, and the separation of religious and social affairs." ${ }^{22}$

The next case that needs to be underlined is how Locke and Rawls define tolerance. Their conceptual thought could be used to explain, and perhaps criticize, how NU and Muhammadiyah perceive tolerance. Locke explains that tolerance can be realized based on the separation of personal beliefs from general actions but with certain limitations, including the state's concern on

\footnotetext{
${ }^{19}$ Menchik, Islam and Democracy in Indonesia, 19.

${ }^{20}$ Ibid., 27.

${ }^{21}$ Ibid., 146.

22 Ibid., 124.
} 
material things. ${ }^{23}$ Meanwhile, for Rawls, the main aspect that can accommodate pluralism-based tolerance is political liberalism. In this liberal democracy, the effort sought is an 'overlapping consensus' which is a set of basic principles publicly justified because all comprehensive doctrines make sense but are only based on reasons derived from their own framework. ${ }^{24}$ Communal tolerance is a concept in 'basic level,' which has a broad meaning but has specific indicators. Based on the survey, the communal tolerance indicators focus on several aspects, including education, worship, political representation, speech, and recognition..$^{25}$ Recognition becomes the estuary of tolerance indicators even with its limitations.

Another aspect that needs to be highlighted from communal tolerance is its pragmatic nature. In this case, pragmatic means not considering tolerance as a virtue but a social control strategy because it is based on a willingness to accept things deemed unpleasant for the sake of stability. ${ }^{26}$ Several aspects emphasized in communal tolerance are group rights, legal pluralism, the separation of religious and social affairs, the primacy of faith, and majority domination. ${ }^{27}$ These aspects make communal tolerance different from the principle of liberal democracy, but it can still be said to be moderate tolerance because of the effort not to discriminate minority groups even though it is part of their interests.

The concept of communal tolerance offered by Menchik, in fact, does not cause any significant problems in influencing individual attitudes, especially in the majority group towards the minority. The problem here is how everyone is able to understand the collective meaning of tolerance. Various negative actions in the form of oppressive and discriminatory religious expressions occur in the field are the results of an intolerant attitude or lack of understanding of the concept of mutual respect. ${ }^{28}$ This has

\footnotetext{
${ }^{23}$ Ibid., 127.

${ }^{24}$ Ibid.

${ }^{25}$ Ibid., 148; Menchik, "Productive Intolerance."

${ }^{26}$ Menchik, Islam and Democracy in Indonesia, 131.

${ }^{27}$ Ibid., 152-154.

${ }^{28}$ Zulkifli, “The Struggle of the Shi' is in Indonesia," 237.
} 
perpetuated the anti-Shia discourse, both textual and contextual, and continues to this day.

In the context of intolerance towards Shia, the main actors are semi-state institutions, government officials, and non-state religious institutions which are clerical bodies, such as the Indonesian Ulema Council (MUI) and are then followed by religious communities and mass organizations. ${ }^{29} \mathrm{NU}$, known as the most tolerant Muslim organization, cannot be separated from the negative stigma against Shia. In the late days of the New Order, before the introduction of the reform, it was noted in the literature that there were individuals or members of NU at the local level who mobilized mass against the Shia. ${ }^{30}$ The different views between NU at the national and local levels are due to the existence of decentralization in the NU structure as a form of social movement. Several well-known kyai who are affiliated with NU show intolerant attitudes towards minority groups. ${ }^{31}$ This attitude is based on the values of sectarianism attached to them. Especially during the New Order era, with an authoritarian leadership style, making violence against Shia seems unavoidable. ${ }^{32}$ Therefore, many speculate that the image of NU as a tolerant Muslim organization that upholds pluralist values is only fabricated for the sake of political contestation. ${ }^{33}$ Not only NU, but also Muhammadiyah committed unpleasant actions against Shia. Many kyai from East Java regard Shia as not Islam. ${ }^{34}$ These intolerant attitudes then prompted the MUI to issue a fatwa that

${ }^{29}$ Dede Syarif, Iskandar Zulkarnain, and Dicky Sofjan, "Anti Shi'ism in Indonesia: Genealogy, Development, and Methods," HARMONI: Jurnal Multikultural \& Multireligius 16, no. 1 (2017): 27.

${ }^{30}$ Yuka Kayane, “Understanding Sunni-Shi'a Sectarianism in Contemporary Indonesia," Indonesia and the Malay World (2020): 2.

31 Arifianto in Ibid., 3; Marcus Mietzner and Burhanuddin Muhtadi, "Explaining the 2016 Islamist Mobilisation in Indonesia: Religious Intolerance, Militant Groups and the Politics of Accommodation," Asian Studies Review (2018): 6.

32 Formichi, "Violence, Sectarianism, and the Politics of Religion: Articulations of Anti-Shi'a Discourses in Indonesia"; Kayane, "Understanding Sunni-Shi'a Sectarianism in Contemporary Indonesia," 2.

${ }^{33}$ Kayane, "Understanding Sunni-Shi'a Sectarianism," 3.

34 Zulkifli, "The Struggle of the Shi' is in Indonesia," 270. 
falsified Shia's teachings. ${ }^{35}$ The aim is not only to attack Shia followers but also to make their teachings not followed by other Muslims in Indonesia.

In the sense of tolerance, the Prophet Muhammad set very good examples by respecting other beliefs. ${ }^{36}$ One of them is in the Medina Charter, which shows the pluralist character of the Prophet Muhammad. Besides, there is also historical evidence that provides an example that Islam-even when holds power-is able to coexist with other religions and can lead a harmonious and peaceful life. ${ }^{37}$ But in reality, there are still many majority groups that do not give space to minorities nowadays. This is because there are different understandings of the jurisprudence of Islam. Influenced by the Wahhabi interpretation of Saudi Arabia on Islam, discriminatory attitudes have emerged leading to intolerance and religious hatred. ${ }^{38}$ The attitude of Islamic countries and the conflict between Saudi Arabia and Islam, causing Sunnimajority countries to also voice anti-Shia propagation.

\section{Anti-Shia Discourse in Indonesia}

Before we delve into how the term anti-Shia emerged in Indonesia, we need to understand the factors that cause religious intolerance, especially among Muslims. Khan et. al. summarizes several reasons why some Muslims are intolerant to other religious communities including 'other Muslims' who have different teachings, including: 1) ideological politicization linked to the progress of post-colonial Islamic politics to develop social, economic, and political limitations of the Muslim-majority countries; 2) religious extremism associated with the worldwide spread of allegedly intolerant explanation of Islam encouraged by Salafism; 3) radicalization is related to the result of the invasion of

${ }^{35}$ Ibid., 271.

${ }^{36}$ Formichi, "Violence, Sectarianism," 3.

${ }^{37}$ Sean William White (2010) in Ahmad Fauzi Abdul Hamid, "Syariahization of Intra-Muslim Religious Freedom and Human Rights Practice in Malaysia: The Case of Darul Arqam," Contemporary Southeast Asia 38, no. 1 (2016): 36.

38 Turan Kayaoglu, "Explaining Interfaith Dialogue in the Muslim World," Politics and Religion 8, no. 2 (2015): 20. 
Muslim-majority countries by the Western military. ${ }^{39}$ From the explanations above, we can see that the attitude of some Muslims is inseparable from the influence of the dynamics of discourse about Islam developing globally, including in this case, Sunni-Shia issue.

Many terms can be embedded in anti-Shia, be it propagation, movement, or discourse. This article uses the term discourse because it only discusses anti-Shia which has been addressed by many prior works. With the existence of international-based sectarian tensions, this anti-Shia discourse has become a global and local issue that perpetuates "othering" attitudes in the form of discrimination with violence. ${ }^{40}$ On a global level, it can be said that the tension between Sunni-Shia is also part of the political issue that intersects with majoritarianism. Many studies have shown that the intra-Muslim tensions developed in the Middle East and the wider Muslim world are related to the abuse of political identity by political elites and authoritarian leaders. ${ }^{41}$ Although it cannot be denied that there is a history of tensions between the two groups, it is more polarized for political purposes. In fact, there are many schools of Islam in the world, but only Sunni-Shia cases gain the most attention. The conflict between Sunni-Shia is divided into three dimensions; identity, fellowship, and the ideological, which is closely related to sectarianism. ${ }^{42}$ The three of them are the same as the background of the tensions between Sunnis and Shia. In the last decade, tensions have even involved violence in various countries around the globe. ${ }^{43}$ Indonesia is also one of the countries that have committed violence against minority groups. The data show that since 2008, there are assumptions that there is an attempt by Iran to spread their revolution, which has

${ }^{39}$ Issa Khan et al., "A Critical Appraisal of Interreligious Dialogue in Islam," SAGE Open 10, no. 4 (2020): 4.

${ }^{40}$ Formichi, "Violence, Sectarianism," 2.

${ }^{41}$ Dino Krause, Isak Svensson, and Göran Larsson, "Why Is There So Little Shia-Sunni Dialogue? Understanding the Deficit of Intra-Muslim Dialogue and Interreligious Peacemaking," Religions 10, no. 567 (2019): 1.

42 Ibid., 3.

${ }^{43}$ Ibid., 4 . 
influenced the Indonesian government to be vigilant. ${ }^{44}$ The antiShia discourse was then internalized into internal problems in many countries. The values instilled in society regarding Shia include:

“... First, Shi' as were depicted as criminals upsetting the country's social order; second, public religious figures known for their Shi'a sympathies were "accused" of undermining Sunni Islam. Thirdly, religious scholars of various affiliations embraced a dogmatic approach, dedicating their time and efforts to elucidating the doctrinal differences (and social dangers) of Shi'a Islam; the 1980s and early 1990s were dotted with meetings and seminars tackling, either directly or indirectly, the differences between Sunni and Shi'a Islam. "45

Criminalization is not only experienced by Shia, but also by their sympathizers. ${ }^{46}$ This happened because they were considered to have the potential to convert and become part of the Shia. However, in reality, the number of Shia followers is only a few and has not developed in Indonesia. The Shia community is divided into three groups: the Association of Indonesian Ahlul Bait (IJABI), Ahlul Bait Indonesia (ABI), and the Organization of Ahlul Bait for Social Support and Education (OASE) whose total members are approximately 2.5 million people. ${ }^{47}$ With a small number of followers, the Muslim community definitely should not feel threatened by the existence of Shia in Indonesia.

The negative portrayal of Shia continues to make people intolerant of Shi'ism and even their supporters. The anti-Shia campaign, which initially only took the form of intellectual-based symbolic violence such as through books, seminars, and mass media among elite Muslims, turns into physical violence. ${ }^{48}$ Many Arabic books containing anti-Shia propagation were translated into Indonesian for distribution to the public. Many seminars debating Sunni-Shia teachings are held by the religious community. The main case that most often arises in debates is about the practice of nikah mut'ah (contract marriage), which even

\footnotetext{
${ }^{44}$ Formichi, "Violence, Sectarianism," 5.

${ }^{45}$ Ibid., 9.

46 Sofjan, "Minoritization and Criminalization of Shia Islam," 39.

${ }^{47}$ Syarif, Zulkarnain, and Sofjan, "Anti Shi'ism in Indonesia," 2.

${ }^{48}$ Ibid., 26.
} 
caused the Ministry of Religious Affairs at that time to speak up to discuss the issue. ${ }^{49}$

The peak was indicated by an incident in Sampang. The years 1999-2001 were the beginning of the mobilization that led to physical violence against the Shia community. ${ }^{50}$ The end of the New Order era did not stop the anti-Shia propagation in the intellectual sphere and actually made things worse. Since then, along with political dynamics, the attitude of Sunni Muslims in Indonesia has also experienced unstable dynamics. ${ }^{51}$ Moreover, there has also emerged a formal organization that openly has antiShia values. Known as ANAS (Aliansi Nasional Anti Syiah/National Anti-Shia Alliance), they work in an organized manner by developing their network as a systematic strategy for anti-Shia campaign. ${ }^{22}$ Violence continues, causing the Shia community to experience expulsion and become refugees. The peak of physical violence took place in the 2006-2013 period. ${ }^{53}$ The most severe violence occurred in Sampang in 2011. The Shia Sampang residents experienced persecution and criminalization. ${ }^{54}$ This incident made them homeless and had to move their dwellings. After this incident, it was not that more and more Muslims were sympathetic to the Shia community, but more and more Muslim leaders were involved in the anti-Shia movement. ${ }^{55}$ The more involved in the movement, the more successful the anti-Shia discourse is in the socio-political dynamics that perpetuate the

${ }^{49}$ Formichi, “Violence, Sectarianism," 10.

${ }^{50}$ Ibid., 22.

${ }^{51}$ Dini Permana Sari, Yuminah, and Benny Herlena, "The Dynamics of Sunni and Shia Relationship: Majority and Minority Conflicts, in Psychological Perspective," Proceedings of the 2nd International Colloquium on Interdisciplinary Islamic Studies (ICIIS) (2020): 8; Al Makin, "Homogenizing Indonesian Islam: Persecution of the Shia Group in Yogyakarta," Studia Islamika 24, no. 1 (2017): 6.

52 Syarif, Zulkarnain, and Sofjan, "Anti Shi'ism in Indonesia," 32.

${ }^{53}$ Formichi, "Violence, Sectarianism," 26.

54 M. Khusna Amal, "Anti-Shia Mass Mobilization in Indonesia's Democracy: Godly Alliance, Militant Groups and the Politics of Exclusion," Indonesian Journal of Islam and Muslim Societies 10, no. 1 (2020): 27; Sofjan, "Minoritization and Criminalization of Shia Islam in Indonesia," 38.

${ }^{55}$ Syarif, Zulkarnain, and Sofjan, "Anti Shi'ism in Indonesia," 32. 
values of sectarianism. ${ }^{56}$ This is especially so if the mainstream Muslim organizations have come to speak out. Among the Muslims who campaigned for anti-Shia, Persis and Al-Ershad, known as Muslim reformist groups, were the most active in giving negative responses to Shia. ${ }^{57}$ Large organizations that are considered to be tolerant and pluralist are also not spared from the anti-Shia movement. Many NU and Muhammadiyah scholars agreed to prevent the spread of Shia, especially in East Java. ${ }^{58}$ In the end, areas that voiced anti-Shia spread to many regions in Indonesia. However, there are also Muslim leaders who continue to support the Shia community in order to obtain their rights as part of Indonesian citizens.

\section{Muslim Intellectuals and Communities' Responses}

Whether on behalf of groups or individuals, different responses emerged from Muslim intellectuals and Islamic organizations towards Shia. Many are pro against anti-Shia propagation, some do not agree, and there are also those who remain neutral by carrying a narrative of religious moderation. As an influential non-state religious institution, MUI from the start has supported anti-Shia propagation. Even though it did not issue a specific fatwa, MUI took a stance by issuing a public statement stating that Shia is a heretical teaching that Muslims in Indonesia need to be aware of, because it is in accordance with the statement from the Department of Religious Affairs (now Ministry of Religious Affairs) that "flow" Shia disturbs social and religious harmony. ${ }^{59}$ The Department of Religious Affairs then issued a circular on the prevention of Shia infiltration which was distributed internally. MUI plays an active role in voicing that Shia teachings are contradictory to existing historical facts. Groups that are also loud in the anti-Shia movement are Persis and Al-Irsyad. ${ }^{60}$ They continue to urge MUI to issue fatwas against Shi'a. However, even without a fatwa, the MUI, which has an influence on policy-

\footnotetext{
${ }^{56}$ Kayane, “Understanding Sunni-Shi'a Sectarianism," 3.

57 Zulkifli, "The Struggle of the Shi' is in Indonesia," 260.

${ }^{58}$ Ibid., 265.

${ }^{59}$ Ibid.; Formichi, "Violence, Sectarianism," 7.

${ }^{60}$ Zulkifli, "The Struggle of the Shi' is in Indonesia," 260.
} 
making as well as on society is able to mobilize the masses and urge them to be careful not to follow Shia teachings. ${ }^{61}$ There were also MUI figures who were also part of the government officials who were not involved in anti-Shia propagation, such as Quraish Shihab, who is a member of the MUI and Minister of Religious Affairs in 1998. He was involved in many debating discussions between Sunnis and Shia but stood in the middle and tended to be neutral. In fact, he was accused of being a Shia supporter but denied this and this was supported by NU figures. ${ }^{62}$ Finally, in May 1998 his position as Minister ended.

As organizations with a tolerant, inclusive, and pluralist image, NU and Muhammadiyah show different attitudes. At least, at the central level, NU and Muhammadiyah showed a neutral stance. NU central figures such as Abdurrahman Wahid and Said Agil Siradj are even more than neutral because they try to open up space for Shia Muslims in Indonesia so that they are sometimes accused of being 'agents' of spreading Shia teachings in Indonesia. ${ }^{63}$ Not only that but there are also many people who think that the figures who support Shia are liberal and secular. Abdurrahman Wahid, who was the president, later recognized IJABI as a national Shia organization, which for him can be used as a starting point for Shia to get the same recognition and rights as Indonesian citizens. ${ }^{64}$ This moderate and even supportive form of response is only done by a few intellectual Muslims who are known as tolerant and pluralists.

Another large organization, namely Muhammadiyah, chose to be neutral towards the Sunni-Shia conflict by not supporting the anti-Shia movement. ${ }^{65}$ However, high-ranking officials at Muhammadiyah showed different responses. Din Syamsudin who became chairman of Muhammadiyah in 2014-2015 showed a negative response to Shia by saying it was deviant teaching in the Sunni-Shia debate against a Shia figure. ${ }^{66}$ His argument used

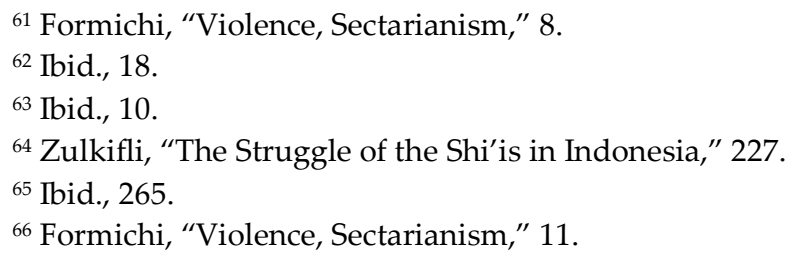


unkind words that emphasized his negative view of Shia teachings. Long before that, when the position of chairman of Muhammadiyah was still held by Amien Rais, Muhammadiyah showed a moderate attitude towards Shia. Amien Rais is a Muslim intellectual who has sympathy for Shia followers. ${ }^{67}$ However, his attitude was widely opposed by many parties.

Another intellectual Muslim who was moderate and sympathetic to Shia was Nurcholish Madjid. He expressed a statement criticizing intolerant and discriminatory attitudes that according to him sectarianism and fanaticism only show the authenticity of polytheism. ${ }^{68}$ Nurcholish Madjid shows a neutral attitude when in the formal atmosphere of seminars that discuss Sunni-Shia. He defended Shia by showing an objective attitude based on scientific narratives. ${ }^{69}$ He has always emphasized that Shia teachings are not much different from Sunnis and are still part of Islam. Although he knows that his attitude has often come under fire from many Sunnis Muslims.

Both positive and negative responses to the Shia have continued today. Both responses from organizations and individuals, various different views have always been discussed in the formal and intellectual realms. Sunni Muslims who have an anti-Shia view, think that Sunni teachings based on ahl al-sunnah wal jama'ah need to be defended and avoided from various practices that could pose a threat. ${ }^{70}$ Their argument also states that Shia is not only a Sunni threat but also a threat to social stability in Indonesia. Meanwhile, Sunni Muslims who support Shia have arguments about protection for minority groups and support arguments that basically Indonesian people are known as pluralistic and tolerant people. ${ }^{71}$ Given these different views, what is needed is an intra-Muslim dialogue. By using scientific-based discourses, the dialogue will be more effective and right on target.

\footnotetext{
${ }^{67}$ Zulkifli, "The Struggle of the Shi' is in Indonesia," 298.

${ }^{68}$ Formichi, "Violence, Sectarianism," 11.

${ }^{69}$ Zulkifli, "The Struggle of the Shi'is in Indonesia," 299.

${ }^{70}$ Formichi, "Violence, Sectarianism," 25.

${ }^{71}$ Zulkifli, "The Struggle of the Shi'is in Indonesia," 93.
} 


\section{The Dialogue}

Abu-Nimer in his article firmly states that 'dialogue is a very dangerous business'.$^{72}$ Not without reason, it arises in as much as trying to understand two or more parties with different beliefs. It is clear that the purpose of dialogue is not to seek absolute agreement. $^{73}$ However, with dialogue, differences can be understood as a reality. At this point, dialogue must work to harmonize differences between groups and handle values and beliefs that shall justify prejudice and exclusion of others. ${ }^{74}$ Moreover, a new fact mentions that dialogue is very important to be considered as an effective prevalent method for peacebuilding between different religious and political groups. ${ }^{75}$ Since this article specifically discusses religion, what is needed here is interfaith dialogue. In this sense, interfaith dialogue can be used as a crucial tool to reduce tensions between religious groups among their adherents around the world.

Interreligious and intrareligious issues can be resolved by means of a dialogue involving the disputing parties. ${ }^{76}$ Interfaith dialogue is part of faith-based diplomacy which, according to some scholars, aims for peacemaking through corrections to the issue of religious antagonism..$^{77}$ In interfaith dialogue, various approaches can be made. According to Eck, the interfaith dialogue approach is divided into the dialogue of life, dialogue of learning, dialogue in community, and dialogue within each of which has a role in its implementation. ${ }^{78}$ Meanwhile, according to Abu-Nimer, interfaith dialogue can be carried out through the following approaches: spirituality, rituals, scripture and sacred text, and

72 Mohammed Abu-Nimer, "The Miracles of Transformation through Interfaith Dialogue: Are You a Believer?," in Interfaith Dialogue and Peacebuilding, ed. David R. Smock (United States Institute of Peace Press, 2002), 15.

${ }^{73}$ Khan et al., "A Critical Appraisal of Interreligious Dialogue in Islam," 2.

${ }^{74}$ Abu-Nimer, "The Miracles of Transformation," 23.

75 Tajudeen Olushola Toki, Muhammad Aliyu Gambari, and Muhammad Ismail Hadi, "Peace Building and Inter-Religious Dialogue in Nigeria," Journal of Islam in Nigeria 1, no. 1 (2015): 105.

${ }^{76}$ Diana Eck, "Interfaith Dialogue in the New Religious America," Review and Expositor 114, no. 1 (2017): 31.

${ }^{77}$ Kayaoglu, “Explaining Interfaith Dialogue," 1.

${ }^{78}$ Eck, "Interfaith Dialogue," 26. 
secondary and universal language of peace versus primary language. ${ }^{79}$ Dialogue does not only involve intellectual entities, but can also involve moral, spiritual material, and other affective beings. ${ }^{80}$ The involvement of all beings in humans can lead to understanding among people in dialogue. Dialogue is two-way communication in which both parties respond to each other. Ideal communication can bridge misunderstandings and mutual ignorance between two parties with culturally different views and allow them to talk to each other about their respective views using their own language. ${ }^{81}$ By reducing their respective egos in order to reduce tension and achieve peaceful goals, actors involved in dialogue must have a pluralistic view that does not always justify their faith so as to avoid conflict polarization. ${ }^{82}$ This interreligious and intrareligious dialogue is not easy to carry out. What makes dialogue difficult is not because it is carried out by adherents of diverse religions, but because it is carried out among human beings who have diverse views. ${ }^{83}$ Therefore, someone who wants to do dialogue must first dialogue with himself by responding to problems objectively. Religious and theological reflections can encourage a person's heart to be more open even when experiencing a religious crisis. ${ }^{84}$ Having an open heart will make it easier for someone to understand and accept differences.

The two terms interreligious and intrareligious dialogue actually have differences. Intrareligious dialogue has meaning when someone deepens their faith which appears before, during, and after religious rendezvous. ${ }^{85}$ It can be said that intrareligious dialogue is intrapersonal communication by asking oneself about one's faith. Self-criticality is the main requirement for someone to

79 Abu-Nimer, "The Miracles of Transformation," 17-21.

${ }^{80}$ Gerrard V. Hall, "Inter or Intra-Religious Dialogue?," Australian eJournal of Theology (2010): 1.

${ }^{81}$ Raimon Panikkar, The Intrareligious Dialogue (Mahwah: Paulist Press, 1999), 10.

82 Peter Admirand, "Humbling the Discourse: Why Interfaith Dialogue, Religious Pluralism, Liberation Theology, and Secular Humanism Are Needed for a Robust Public Square," Religions 10, no. 450 (2019): 2.

${ }^{83}$ Hall, “Inter or Intra-Religious Dialogue?," 2.

${ }^{84}$ Panikkar, The Intrareligious Dialogue, 48.

${ }^{85}$ Hall, “Inter or Intra-Religious Dialogue?,” 11. 
enter the arena of genuine religious dialogue. ${ }^{86}$ With this attitude, we can achieve the goal of dialogue, namely understanding. The essence of dialogue is not like a debate which can divert one side or homogenize religious teachings. Because the substance of interreligious dialogue is not reaching an agreement like in a conference.

Dialogue among Muslims from different branches can be referred to as intra-Muslim dialogue. Peacemaking efforts through dialogue are carried out by many Muslim actors in many countries around the world due to long-standing sectarian conflicts between Sunni and Shia. ${ }^{87}$ The continuing sectarian tension has led world organizations to step in to help solve the problem. Initially, the aim of the dialogue was often diverted because it was used as an inclusive political strategy to protect and spread "true Islam" by delegitimizing their opponents. ${ }^{88}$ According to scholars, the real dialogue between Sunni-Shia has not been carried out optimally. There are several arguments for the insufficient global Sunni-Shia dialogue:

"First, we discuss the possibility that Shia-Sunni dialogue does not exist because Shia-Sunni tensions are epiphenomenal and there is, in essence, no. Shia-Sunni divide to bridge in the first place. Second, we discuss whether the lack of Shia-Sunni dialogue is simply a reflection of interreligious dialogue, ... Third, we discuss the possibility that the apparent lack of Shia Sunni dialogue can be explained by arguing that dialogue and peacemaking occur through other institutional channels or informally through local actors, for example, tribal leaders, village elders, or other local authorities." 89

Many parties have encouraged the establishment of dialogue between Sunni-Shia in order to create peace. On the other hand, there are also those who argue that dialogue is not really necessary because it is reflected in the lack of existing Sunni-Shia dialogue. ${ }^{90}$ The statement is actually based on the concern that there is a division between the Sunni-Shia which is bigger because each has

${ }^{86}$ Panikkar, The Intrareligious Dialogue, 74.

${ }^{87}$ Krause, Svensson, and Larsson, "Why Is There So Little Shia-Sunni Dialogue?," 2.

${ }^{88}$ Kayaoglu, "Explaining Interfaith Dialogue," 2.

89 Krause, Svensson, and Larsson, "Why Is There So Little Shia-Sunni Dialogue?," 2-3.

${ }^{90}$ Ibid., 6. 
a stigma and prejudice towards the other. However, along with the rampant conflicts involving violence, people, especially in the intellectual realm, again voiced the necessity to conduct a dialogue. The lack of dialogue also causes the conflict between Saudi Arabia and Iran to become increasingly tense, followed by an increase in sectarian violence in other Muslim countries. ${ }^{91}$ Therefore, countries in the Middle East re-initiated interfaith activism to reduce Sunni-Shia tensions. One of them is Turkey, which is a secular Muslim majority country, promoting religious movements to perform interfaith dialogue which is in a moderate stance by giving distance to radical and political Islamists. ${ }^{92}$ Another country that is committed to dialogue is Jordan. There are three aims of the Jordan government to carry out interfaith dialogue, including: opposing domestic Islamic opposition; in response to alleviating sectarian tension in the Middle East; and to promote an image of a moderate society on the international scene. ${ }^{93}$ Saudi Arabia also doesn't want to be left behind in taking the initiative to carry out interfaith dialogue. Although known as a country that complies with Wahhabism, government officials have efforts to reduce religious discrimination against Shia Islam and non-Muslims. ${ }^{94}$ Countries that initially had doubts about carrying out dialogue have now become more open to dialogue.

It is different from Indonesia. In the past, Indonesia has been more active in holding forums for intra-Muslim dialogue. The practice of interfaith dialogue has been carried out for centuries by various interfaith communities in Indonesia and according to many scholars, this dialogue has a great role in shaping the understanding of religious plurality and cultural diversity in this Muslim-majority country. ${ }^{95}$ When Abdurrahman Wahid served as chairman of the MUI (1984-1999), a tolerant and pluralist image played a pivotal role because he always advocated interreligious

\footnotetext{
${ }^{91}$ Ibid., 12.

${ }^{92}$ Ibid., 4.

${ }^{93}$ Ibid., 16.

${ }^{94}$ Ibid., 17.

95 Izak Y. M. Lattu, “Beyond Interreligious Dialogue: Oral-Based Interreligious Engagements in Indonesia," in Volume 10: Interreligious Dialogue, ed. Giuseppe Giordan and Andrew P. Lynch (Leiden, Boston, 2019), 73.
} 
dialogue. ${ }^{96}$ The aim of the initiative to carry out interreligious dialogue is to create religious harmony between religious communities in Indonesia. The dialogue that was held at that time was caused by the narrative of the spread of Shia in Indonesia. ${ }^{97}$ The involvement of many Muslim actors in dialogue shows more neutral responses without showing partiality. However, a neutral attitude does not solve the problem because it still perpetuates the intolerance and discrimination ${ }^{98}$ of the majority against Shia Muslims in Indonesia. Not only are their rights not fulfilled, but they also become victims of physical violence or hate speech, and they often become targets of criminalization.

The forms of dialogue that can be implemented are very diverse and are not limited to formal settings. Because at this time, the dialogue has expanded to social action than previously which was finite to a textual discussion..$^{99}$ Textual discussions that tend to separate differences are prone to get clogged. When there is no common ground from ideological and theological debates, collaboration in real action can make interreligious groups interact harmlessly. ${ }^{100}$ To be able to actualize this collaboration, it is necessary to have an understanding of the value of pluralism. Back to the question of intrareligious dialogue, that understanding begins with the self who believes that the God of all beings has chosen plurality and commands us to respect others. ${ }^{101}$ One of the efforts to cultivate the value of pluralism is through education. Being able to respect and appreciate differences is the goal of pluralism education since it emphasizes humanity that passes through the barriers of religious exclusivity. ${ }^{102}$ In this case, what needs to be considered is the type of pluralism that allows creating dialogue. Interactive pluralism that recognizes the existence of

${ }^{96}$ Kayane, "Understanding Sunni-Shi'a Sectarianism," 2.

${ }_{97}$ Zulkifli, "The Struggle of the Shi'is," 301.

${ }^{98}$ Bojan Žalec and Martina Pavlíková, "Religious Tolerance and Intolerance," European Journal of Science and Theology 15, no. 5 (2019): 42.

${ }^{99}$ Lattu, "Beyond Interreligious Dialogue," 71.

100 Abu-Nimer, "The Miracles of Transformation," 24.

${ }^{101}$ Eck, "Interfaith Dialogue," 31.

102 Made Saihu and Abdul Aziz, "Implementasi Metode Pendidikan Pluralisme Dalam Mata Pelajaran Pendidikan Agama Islam," Jurnal Pendidikan Islam 5, no. 01 (2020): 133. 
different groups and asserts the importance of dialogue, mutual understanding, and mutual recognition is a promising type of pluralism. ${ }^{103}$ It can even be recommended to incorporate interaction-based pluralism education that emphasizes the importance of interreligious dialogue into the religious education curriculum. Therefore, an intra-Muslim dialogue that is more open and filled with pluralist values is possible to be implemented to generate mutual understanding and mutual respect between Sunni-Shia in Indonesia.

\section{Conclusion}

Based on the above explanation, we can see that the conflict between Sunni-Shia in Indonesia and around the world is influenced by sectarianism which has been brought about by the political conflict between Saudi Arabia and Iran. Indonesia is one of the countries that have concerns about Sunni-Shia tension. In terms of tolerance, Muslim actors have different understandings in responding to Shia followers and how they interpret and define their attitude towards Shia. Those who reject Shia teachings tend to give a negative response to the point of creating an anti-Shia movement as a form of vigilance so that Shia teachings do not develop in Indonesia. Muslim actors who are moderate have greater tolerance by providing proper space for Shia. They even took initiatives to hold a dialogue between Sunni-Shia to meet mutual understanding and mutual respect between the two of them. Intra-Muslim dialogues discussing Sunni-Shia have been carried out in many countries including Indonesia. However, the lack of comprehensive dialogue prevents the objectives from being fully achieved. Thus, a lively dialogue is needed where each member is more open and instills the value of pluralism in order to be able to understand one another.

103 Martin Ubani et al., “Dialogue, Worldview Inclusivity, and IntraReligious Diversity: Addressing Diversity through Religious Education in the Finnish Basic Education Curriculum," Religions 11, no. 581 (2020): 6. 


\section{References}

Abu-Nimer, Mohammed. "The Miracles of Transformation through Interfaith Dialogue: Are You a Believer?" In Interfaith Dialogue and Peacebuilding, edited by David R. Smock, 15-32. United States Institute of Peace Press, 2002.

Achmad, Mukhsin. "A Hermeneutical Analysis on Fatwa of The Council of Indonesian Ulama Dealing with Discriminating Shia in Indonesia." Madania 23, no. 1 (2019): 33-46.

Admirand, Peter. "Humbling the Discourse: Why Interfaith Dialogue, Religious Pluralism, Liberation Theology, and Secular Humanism Are Needed for a Robust Public Square." Religions 10, no. 450 (2019): $1-16$.

Almu'tasim, Amru. "Berkaca NU Dan Muhammadiyah Dalam Mewujudkan Nilai-Nilai Moderasi Islam Di Indonesia." Tarbiya Islamia 8, no. 2 (2019): 199-212.

Amal, M. Khusna. "Anti-Shia Mass Mobilization in Indonesia's Democracy: Godly Alliance, Militant Groups and the Politics of Exclusion." Indonesian Journal of Islam and Muslim Societies 10, no. 1 (2020): 25-48.

- - - "Protecting Civil Rights Amidst Rising Illiberalism in Indonesia's Democracy: State's Response to Sharia-Based Violence Against Shi'a Groups." Ulumuna 24, no. 2 (December 31, 2020): 296-319.

Arifianto, Alexander R. "Practicing What It Preaches? Understanding the Contradictions between Pluralist Theology and Religious Intolerance within Indonesia's Nahdlatul Ulama." Al-Jami'ah: Journal of Islamic Studies 55, no. 2 (December 15, 2017): 241-264.

Bruinessen, Martin van, ed. Contemporary Developments in Indonesian Islam: Explaining the "Conservative Turn." Pasir Panjang: ISEAS Publishing, 2013.

Deth, Jan W van, José Ramón Montero, and Anders Westholm, eds. Citizenship and Involvement in European Democracies: A Comparative Analysis. Routledge, 2009.

Eck, Diana. "Interfaith Dialogue in the New Religious America." Review and Expositor 114, no. 1 (2017): 25-33.

Formichi, Chiara. "Violence, Sectarianism, and the Politics of Religion: Articulations of Anti-Shi'a Discourses in Indonesia." Indonesia 98 (2014): 1-27.

Hall, Gerrard V. “Inter or Intra-Religious Dialogue?” Australian eJournal of Theology (2010): 1-13. 
Hamid, Ahmad Fauzi Abdul. "Syariahization of Intra-Muslim Religious Freedom and Human Rights Practice in Malaysia: The Case of Darul Arqam." Contemporary Southeast Asia 38, no. 1 (2016): 28-54.

Hefner, Robert W., ed. Routledge Handbook of Contemporary Indonesia. Abingdon: Routledge, 2018.

Hoffman, Michael. "Religion and Tolerance of Minority Sects in the Arab World." Journal of Conflict Resolution 6, no. 2-3 (2020): 432-458.

Irfani, Adistya Iqbal, Moh. Yasir Alimi, and Rini Iswari. "Toleransi Antar Penganut Nahdhatul Ulama, Muhammadiyah, Dan Kristen Jawa Di Batang." Jurnal Komunitas 5, no. 1 (2013): 1-13.

Kayane, Yuka. "Understanding Sunni-Shi'a Sectarianism in Contemporary Indonesia." Indonesia and the Malay World (2020): 1-19. Kayaoglu, Turan. "Explaining Interfaith Dialogue in the Muslim World." Politics and Religion 8, no. 2 (2015): 236-262.

Khan, Issa, Mohammad Elius, Mohd Roslan Mohd Nor, Mohd Yakub Zulkifli, Kamaruzaman Noordin, and Fadillah Mansor. "A Critical Appraisal of Interreligious Dialogue in Islam." SAGE Open 10, no. 4 (2020): 1-10.

Krause, Dino, Isak Svensson, and Göran Larsson. "Why Is There So Little Shia-Sunni Dialogue? Understanding the Deficit of Intra-Muslim Dialogue and Interreligious Peacemaking." Religions 10, no. 567 (2019): 1-17.

Lattu, Izak Y. M. "Beyond Interreligious Dialogue: Oral-Based Interreligious Engagements in Indonesia." In Volume 10: Interreligious Dialogue, edited by Giuseppe Giordan and Andrew P. Lynch, 70-90. Leiden, Boston, 2019.

Makin, Al. "Homogenizing Indonesian Islam: Persecution of the Shia Group in Yogyakarta." Studia Islamika 24, no. 1 (2017): 1-32.

Menchik, Jeremy. Islam and Democracy in Indonesia: Tolerance without Liberalism. New York: Cambridge University Press, 2016.

- - - "Productive Intolerance: Godly Nationalism in Indonesia." Comparative Studies in Society and History 56, no. 3 (2014): 591-621.

Menchik, Jeremy, and Thomas B. Pepinsky. "Islam, Identity, and the Organizational Roots of Political Tolerance." SSRN Electronic Journal (2018): 1-29.

Mietzner, Marcus, and Burhanuddin Muhtadi. "Explaining the 2016 Islamist Mobilisation in Indonesia: Religious Intolerance, Militant Groups and the Politics of Accommodation." Asian Studies Review (2018): 1-19. 
Muhtarom, Ali. "The Study of Indonesian Moslem Responses on SalafyShia Transnational Islamic Education Institution." Jurnal Ilmiah Islam Futura 17, no. 1 (2017): 73-95.

Panikkar, Raimon. The Intrareligious Dialogue. Mahwah: Paulist Press, 1999.

Saihu, Made, and Abdul Aziz. "Implementasi Metode Pendidikan Pluralisme Dalam Mata Pelajaran Pendidikan Agama Islam." Jurnal Pendidikan Islam 5, no. 01 (2020): 131-150.

Sari, Dini Permana, Yuminah, and Benny Herlena. "The Dynamics of Sunni and Shia Relationship: Majority and Minority Conflicts, in Psychological Perspective." Proceedings of the 2nd International Colloquium on Interdisciplinary Islamic Studies (ICIIS) (2020): 1-15.

Sofjan, Dicky. "Minoritization and Criminalization of Shia Islam in Indonesia." Journal of South Asian and Middle Eastern Studies 39, no. 2 (2016): 29-44.

Syarif, Dede, Iskandar Zulkarnain, and Dicky Sofjan. "Anti Shi'ism in Indonesia: Genealogy, Development, and Methods." HARMONI: Jurnal Multikultural \& Multireligius 16, no. 1 (2017): 24-37.

Toki, Tajudeen Olushola, Muhammad Aliyu Gambari, and Muhammad Ismail Hadi. "Peace Building and Inter-Religious Dialogue in Nigeria." Journal of Islam in Nigeria 1, no. 1 (2015): 104-116.

Ubani, Martin, Elisa Hyvärinen, Jenni Lemettinen, and Elina Hirvonen. “Dialogue, Worldview Inclusivity, and Intra-Religious Diversity: Addressing Diversity through Religious Education in the Finnish Basic Education Curriculum." Religions 11, no. 581 (2020): 1-18.

Žalec, Bojan, and Martina Pavlíková. "Religious Tolerance and Intolerance." European Journal of Science and Theology 15, no. 5 (2019): 39-48.

Zulkifli. "The Struggle of the Shi' is in Indonesia." Leiden University, 2009. 